\title{
The Relationship of a Combination of Human Adipose Tissue-Derived Stem Cells and Frozen Fat with the Survival Rate of Transplanted Fat
}

\author{
Ki-Young Ha ${ }^{1}$, Hojin Park ${ }^{2}$, Seung-Ha Park ${ }^{2}$, Byung-Il Lee ${ }^{2}$, Yi-Hwa Ji ${ }^{3}$, Tae-Yeon Kim ${ }^{4}$, \\ Eul-Sik Yoon ${ }^{2}$ \\ ${ }^{1}$ Daisy Plastic Surgery Clinic, Seongnam; ${ }^{2}$ Department of Plastic Surgery, Korea University Anam Hospital, Korea University College of \\ Medicine, Seoul; ${ }^{3}$ Department of Plastic Surgery, Korea University Ansan Hospital, Korea University College of Medicine, Seoul; \\ ${ }^{4}$ Department of Plastic Surgery, Bundang Jesaeng General Hospital, Seongnam, Korea
}

Background The survival rate of grafted fat is difficult to predict, and repeated procedures are frequently required. In this study, the effects of the freezing period of harvested adipose tissue and the addition of human adipose tissue-derived stem cells (ASCs) on the process of fat absorption were studied.

Methods Adipose tissue was obtained from patients who underwent a lipoaspirated fat graft. The fat tissue was cryopreserved at $-20^{\circ} \mathrm{C}$ in a domestic refrigerator. A total of 40 nude mice were used. The mice in the experimental group received three different subcutaneous injections in the back: an injection of fresh fat and ASCs, an injection of fat that had been frozen for one month and ASCs, and an injection of fat that had been frozen for two months and ASCs. The control mice received fat grafts without ASCs. The mice were sacrificed at four or eight weeks after the procedure, and the grafted fat tissues were harvested. The extracted fat was evaluated using photographic analysis, volume measurements, and histological examination.

Results In the control group, the fat resorption rates four weeks after transplantation in the grafts of fresh fat, fat that had been frozen for one month, and fat that had been frozen for two months were $21.14 \%, 22.46 \%$, and $42.56 \%$, respectively. In the experimental group, the corresponding resorption rates were $6.68 \%, 13.0 \%$, and $33.9 \%$, respectively.

Conclusions ASCs can increase the fat graft survival rate. The use of ASCs in fat grafting can reduce the need for repeated fat grafts and provide good long term results.

Keywords Stem cells / Cryopreservation / Injections, subcutaneous / Adipose tissue
Correspondence: Eul-Sik Yoon Department of Plastic Surgery, Korea University Anam Hospital, Korea University College of Medicine, 73 Inchon-ro, Seongbuk-gu, Seoul 02841 , Korea

Tel: $+82-2-920-5368$

Fax: +82-2-922-7437

E-mail: yesanam2@korea.ac.kr

No potential conflict of interest relevant to this article was reported.

Received: 3 Jun 2015 • Revised: 11 Aug 2015 • Accepted: 17 Aug 2015

pISSN: 2234-6163 • elSSN: 2234-6171 • http://dx.doi.org/10.5999/aps.2015.42.6.677• Arch Plast Surg 2015;42:677-685

\section{INTRODUCTION}

The first autologous transplantation of a fatty mass was performed by Neuber in the 1890s, and fat transplantation using cannulae was pioneered by Miller in the 1920s [1-3]. Interest in autologous fat transplantation has increased along with interest in liposuction. Autologous fat transplantation procedures have the advantage of being capable of creating naturally formed 
body parts with insufficient soft tissue volume or contour imbalances, as well as involving fewer foreign body reactions and less donor morbidity. However, autologous fat transplantation also has drawbacks, such as requiring repeated procedures, because it is difficult to predict the survival rate of transplanted fat. The survival rate of transplanted fat has been reported to vary considerably. Therefore, improving the survival rate of transplanted fat remains a major research goal in the field of autologous fat transplantation [4]. In order to compensate for the fat absorption that arises after fat grafting, repeated fat grafting procedures are required. The commonly accepted methods for performing repeated fat transplantations are obtaining fresh fat in every operation or freezing the fat taken from the first operation and saving it for later use. Harvesting fresh fat in each operation can increase the patient's discomfort, pain, and the overall procedure time, but leads to more satisfactory results. Therefore, frozen fat is commonly used to supplement areas of augmentation with insufficient volume. However, the adipose cells in frozen adipose tissue are transformed by the freezing process in ways that affect their behavior after transplantation. These transformations increase the rate of fat absorption and make it difficult to predict the shape of the surviving fat after transplantation. In addition, these problems become more serious if the frozen fat is stored for a longer period.

Recently, several studies have been conducted to address these issues, and the use of ancillary injections of artificial fillers such as hyaluronic acid has been considered, but it is difficult to inject such fillers in large doses and the resulting texture is more rigid than what is obtained in fat transplantation. In addition, artificial fillers are associated with a higher rate of complications, such as foreign-body granulomas, infection, and inflammation, making it problematic to replace fat transplantations with artificial fillers.

Adipose tissue-derived stem cells (ASCs) are multipotent and can differentiate into adipocytes, chondrocytes, neuronal cells, osteoblasts, and skeletal myocytes, meaning that they are of great clinical value in the fields of tissue engineering and tissue regeneration [5-8]. ASCs have entered clinical use, and research is currently being carried out with the goal of increasing their survival rate during fat transplantation procedures. The causes of the correlation between the use of ASCs and the survival rate of transplanted adipose tissue are unclear. Nevertheless, ASCs have been shown to enhance angiogenesis, and their use in the treatment of myocardial infarction has been associated with revascularization $[9,10]$. These reports suggest that the use of ASCs in the transplantation of frozen adipose tissue can increase the density of adipose tissue due to adipose tissue differentiation, minimal transformation of the fat tissue, and the enhanced survival rate of the fat caused by extensive revascularization. No study has yet evaluated the effect of ASCs on the absorption of cryopreserved fat.

The present study examined the effect of the freezing period and the addition of human ASCs on the process of fat absorption. In addition, the changes in adipose cells over the freezing period and the period after transplantation were assessed histologically, with the goal of identifying the changes that resulted from the addition of human ASCs.

\section{METHODS}

\section{Experimental animals and the collection of adipose tissue}

Nude mice with suppressed immune systems were used, thus avoiding transplant rejection due to the immune response to human adipose tissue. All experimental animals were six-weekold BALB/c males; the weight of each animal was approximately $20 \mathrm{~g}$, and a total of forty mice were included in the study.

Human adipose tissue was collected from two female patients who had visited the plastic surgery department for autologous fat transplantation. They were 27 and 34 years of age, respectively, and their body mass indices were $27 \mathrm{~kg} / \mathrm{m}^{2}$ and $29 \mathrm{~kg} /$ $\mathrm{m}^{2}$, respectively. The patients provided written informed consent before the procedure, based on an experimental protocol approved by the Institutional Animal Care and Use Committee of Korea University Ansan Hospital (AS0646-002).

Fat was harvested three times from the lower abdomen, the flank, and thigh, at one and two months before the experiment and on the day of the experiment. The fat that was harvested one month before the experiment was used to obtain the ASCs. First, in order to acquire the adipose tissue, a tumescent solution was made by adding $20 \mathrm{~mL}$ of lidocaine and $1 \mathrm{~mL}$ of 1:1,000 epinephrine to $1 \mathrm{~L}$ of normal saline, which was injected evenly into the patient's lower abdomen as anesthesia. In order to minimize the destruction of the adipose tissue while taking the tissue sample, approximately half of the injected tumescent solution was aspirated with a needle attached to a 3-mm Coleman suction tube (Coleman cannula, Byron Medical, Tucson, AZ, USA), and a 10-mL syringe (Coleman system, Byron Medical, Tucson, AZ, USA). The aspirated adipose tissue was divided into three layers by three minutes of centrifugation at $800 \times \mathrm{g}$. The upper layer, composed of lipids and various types of cells, and the lower layer, comprising blood, were removed. The adipose cells in the middle layer were separated out.

\section{Preparation of frozen fat and human adipose tissue- derived stem cells}

The adipose tissue taken by the liposuction was cleaned with 
normal saline and phosphate-buffered saline (PBS) (Gibco, Carlsbad, CA, USA), and contaminations of erythrocytes and foreign bodies were removed. The tissue was then sliced into small pieces using sterile surgical scissors and forceps to ensure that it could pass through a needle, and $400 \mathrm{mg}$ were inserted into each syringe and stored in a $-20^{\circ} \mathrm{C}$ freezer. The tissue samples were stored for one or two months for use in the experiment.

The ASCs used for the experiment were dissociated using 0.05\% type IA collagenase (Sigma, St. Louis, MO, USA), after thoroughly cleaning the fatty tissue obtained by liposuction. Subsequently, after neutralizing the activated collagenase with $10 \%$ fetal bovine serum, centrifugation was performed for 10 minutes at $400 \times \mathrm{g}$, and the upper layer of liquid was removed. After refloating the stromal vascular fraction in Dulbecco's modified Eagle medium (DMEM) containing 10\% fetal bovine serum, antibiotics, and an antifungal solution, the impurities were eliminated by filtration through a $70-\mu \mathrm{m}$ mesh. The remainder was inserted into a culture flask and cultured at $37^{\circ} \mathrm{C}$ in a $5 \%$ $\mathrm{CO}_{2}$ incubator for 24 hours. The medium was removed from the flask 24 hours later. The dead cells were removed by repeatedly cleaning the flask with PBS. New DMEM was then added and the cells were subcultured. The medium was replaced every two to three days and subcultured three times to ensure a sufficient supply of cells. After the cell culture was completed, $3 \times 10^{5}$ cells $/ 20 \mu \mathrm{L}$ were stained using Trypan blue.

\section{Verification of human adipose tissue-derived stem cells: fluorescence-activated cell sorter analysis}

Fluorescence-activated cell sorter (FACS) analysis was performed using specific stem cell markers to confirm that the cells used in the experiment were human ASCs. For FACS analysis, cells in their third passage were treated with trypsin on a plate, separated, and cleaned with PBS. The CD73 and CD105 antibodies, which are stem cell markers, and the CD34 and CD45 antibodies, which are hematopoietic stem cell markers, were incubated in a light-blocked space at room temperature for 30 minutes. The cells were cleaned twice with a PBS buffer. In order to fix the cells with the antibodies attached, they were treated with $1 \%$ paraformaldehyde and measured using a FACS machine (Calibu of BD Co., Franklin Lakes, NJ, USA).

\section{Fat transplantation and collection of the transplanted fat} The experiment was carried out on forty BALB/c nude mice that did not have any immune response, and fat samples were injected into the backs of the mice in the control group $(n=20)$ and the experimental group $(n=20)$. Aspirated fat and ASCs from the same donor were used in the experiments. For fat transplantation in the experimental group, $0.1 \mathrm{~mL}$ of DMEM and $1.5 \times 10^{6}$ ASCs were mixed with $0.4 \mathrm{~mL}$ of adipose tissue and injected using 1-mL Luer-Lok syringes designed for fat transplantation and 18-gauge needles. The back of the mouse, where no fat is found in the subcutaneous tissue, was chosen as the injection site in order to avoid confusion when examining the fat at the end of the experiment. The mice were placed under anesthesia with $0.2 \mathrm{~mL}$ of intraperitoneally administered ketamine. The mice in the experimental group received three different subcutaneous injections into the back: $0.4 \mathrm{~mL}$ of fresh fat and $0.1 \mathrm{~mL}$ of DMEM with ASCs, $0.4 \mathrm{~mL}$ of fat that had been frozen for one month and $0.1 \mathrm{~mL}$ of DMEM with ASCs, and $0.4 \mathrm{~mL}$ of fat that had been frozen for two months and 0.1 $\mathrm{mL}$ of DMEM with ASCs. The control mice received three different fat grafts without ASCs: $0.4 \mathrm{~mL}$ of fresh fat, $0.4 \mathrm{~mL}$ of fat that had been frozen for one month, and $0.4 \mathrm{~mL}$ of fat that had been frozen for two months. The three fractionated sections of the back of each mouse were kept separate and blocked from each other. Subsequently, the mice used for the experiment were provided with sterile food and water in a sterile environment.

Ten mice from each group were sacrificed at four and eight weeks after transplantation, and the transplanted adipose tissue was collected.

\section{Analysis of the volume of the transplanted Fat}

After cleaning the collected adipose tissue with normal saline, the fat was inserted into a $2-\mathrm{mL}$ syringe filled with $1 \mathrm{~mL}$ of normal saline, and the increase in the volume of the normal saline was measured.

\section{Histological analysis of the transplanted fat}

The collected adipose tissue was prepared for histological examination by fixation with formalin and embedding in paraffin. After fragmentation of the cell clusters, the middle of the tissue was cut at a thickness of $5 \mu \mathrm{m}$ using an ultra-thin cutter, stained with hematoxylin and eosin, set on slides, and observed using optical microscopy $(40 \times)$ for histological analysis.

\section{Statistical analysis}

The data were expressed as mean values and standard deviations. The IBM SPSS ver. 20.0 (IBM Corp., Armonk, NY, USA) for Windows was used for statistical analysis. The groups were compared using the Kruskal-Wallis test and the Mann-Whitney $\mathrm{U}$ test. P-values $<0.05$ were considered to indicate statistical significance. 


\section{RESULTS}

\section{Gross findings}

No connections were found between the separate fat injections in the backs of the mice, and a thin layer of film formed around the graft areas, making them easy to separate. All changes in volume before tissue harvesting were invisible to the naked eye, and no grossly visible changes were noted in the adipose tissue. In some parts of the tissue, necrosis and extrudates were observed in the center of the adipose tissue (Fig. 1).

\section{Analysis of the volume of the transplanted fat}

Four weeks after the experiment, in the control group, the grafts in which fresh fat was injected showed an absorption rate of $21.1 \%$ (average volume, $0.39 \pm 0.05 \mathrm{~mL}$ ), and the injections of fat that had been frozen for one month showed an absorption rate of $22.5 \%$ (average volume, $0.38 \pm 0.03 \mathrm{~mL}$ ). In the group that received fat that had been frozen for two months, a $42.6 \%$ absorption rate was observed (average volume, $0.29 \pm 0.07 \mathrm{~mL}$ ) (Table 1). In the experimental group, in which ASCs were injected along with the fat, the fresh fat injections showed an absorption rate of $6.7 \%$ (average volume, $0.47 \pm 0.07 \mathrm{~mL}$ ), and the injections with fat that had been frozen for one month and two months showed an absorption rate of $13.0 \%$ (average volume,

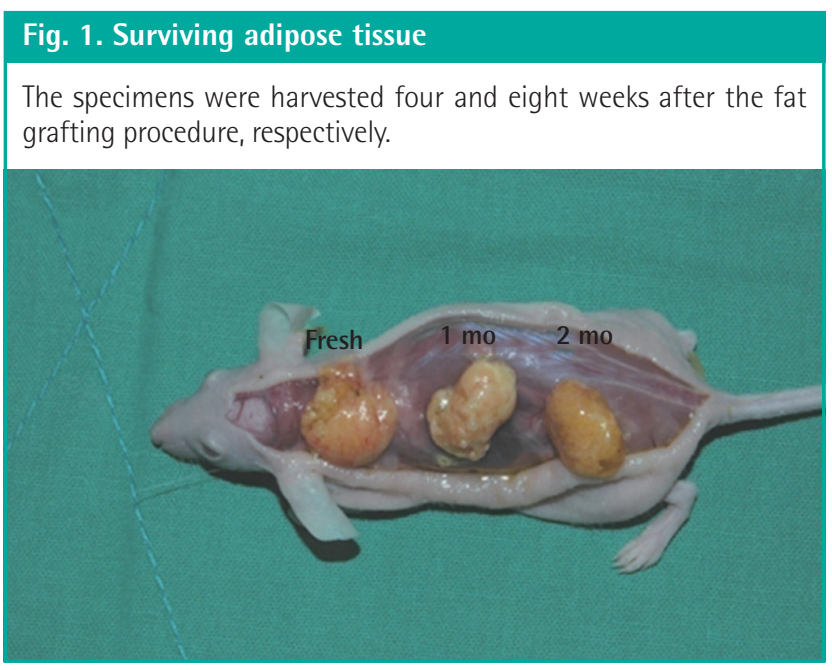

Table 1. The amount of fat tissue harvested from the mice in the control group after four weeks

\begin{tabular}{|lccc|}
\hline Survived volume & Fresh fat & $\begin{array}{c}\text { Fat frozen for } \\
\text { 1 month }\end{array}$ & $\begin{array}{c}\text { 2 } \text { months } \\
\text { mozon for }\end{array}$ \\
\hline $\begin{array}{l}\text { Average } \pm \text { standard } \\
\text { deviation (mL) }\end{array}$ & $0.39 \pm 0.05$ & $0.38 \pm 0.03$ & $0.29 \pm 0.07$ \\
Decrease in volume (\%) $)^{\text {a) }}$ & 21.1 & 22.5 & 42.6 \\
\hline $\begin{array}{l}\text { a) The decrease in volume was defined as [(initial volume - remnant volume)/ini- } \\
\text { tial volume] } \times 100 .\end{array}$ & & & \\
\hline
\end{tabular}

$0.44 \pm 0.06 \mathrm{~mL}$ ) and $33.9 \%$ (average volume, $0.33 \pm 0.11 \mathrm{~mL}$ ), respectively (Table 2). In both the control and experimental groups, no statistically significant difference was observed in the absorption rates in the injections of newly taken fat and the injections of fat that had been frozen for one month, but the fat that had been frozen for two months showed a higher absorption rate. The addition of human ASCs resulted in a decrease in the fat absorption rate (Fig. 2).

Eight weeks after the experiment, the control group showed an absorption rate of $31.76 \%$ (average volume, $0.341 \pm 0.03$ $\mathrm{mL}$ ) in the injections of freshly harvested fat, an absorption rate of $34.52 \%$ (average volume, $0.327 \pm 0.04 \mathrm{~mL}$ ) in the injections of fat that had been frozen for one month, and an absorption rate of $58.02 \%$ (average volume, $0.209 \pm 0.02 \mathrm{~mL}$ ) in the injections of fat that had been frozen for two months (Table 3). In the experimental group, in which human ASCs were injected together with the fat, an absorption rate of $28.6 \%$ (average volume, $0.34 \pm 0.11 \mathrm{~mL}$ ) was found in the injections of fresh fat, while the injections of fat that had been frozen for one month showed an absorption rate of $52.0 \%$ (average volume, $0.24 \pm$

Fig. 2. The volume of surviving fat four weeks after transplantation

ASC, adipose tissue-derived stem cell.

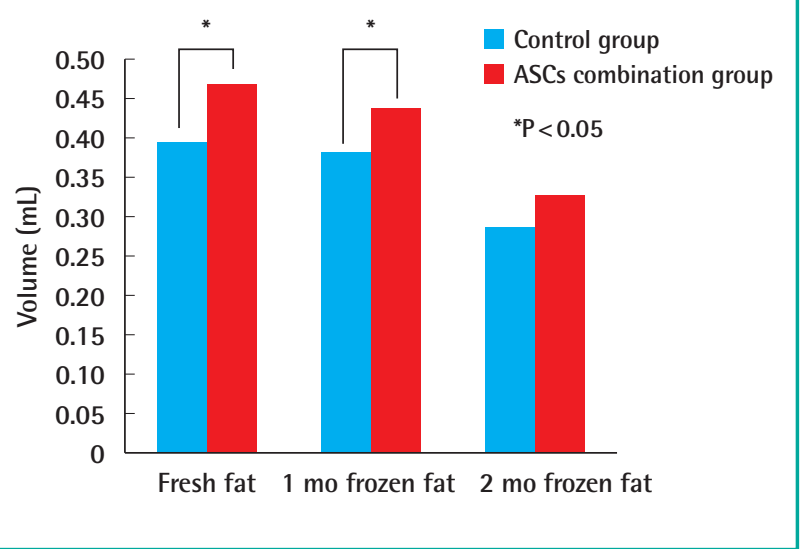

Table 2. The amount of fat tissue harvested from the mice in the adipose tissue-derived stem cell treatment group after four weeks

\begin{tabular}{|lccc|}
\hline Survived volume & $\begin{array}{c}\text { Fresh } \\
\text { fat+ASCs }\end{array}$ & $\begin{array}{c}\text { Fat frozen for } \\
\text { 1 month } \\
\text { +ASCs }\end{array}$ & $\begin{array}{c}\text { Fat frozen for } \\
\text { 2 months } \\
\text { +ASCs }\end{array}$ \\
\hline $\begin{array}{l}\text { Average } \pm \text { standard } \\
\text { deviation }(\mathrm{mL})\end{array}$ & $0.47 \pm 0.07$ & $0.44 \pm 0.06$ & $0.33 \pm 0.11$ \\
Decrease in volume (\%) & 6.68 & 13.0 & 33.9 \\
\hline $\begin{array}{l}\text { ASC, adipose tissue-derived stem cell. } \\
\text { a)The decrease in volume was defined as [(initial volume - remnant volume)/ini- } \\
\text { tial volume] } \times 100 .\end{array}$ \\
\hline
\end{tabular}


$0.12 \mathrm{~mL}$ ), and the injections of fat that had been frozen for two months showed an absorption rate of $66.6 \%$ with (average volume, $0.17 \pm 0.08 \mathrm{~mL}$ ) (Table 4).

The results eight weeks after implantation also showed small differences between the injections with fresh fat and the injections with fat that had been frozen for one month. The absorption rate of the injections of fat that had been frozen for two months was higher than that of the other two sets of injections. These results show that frozen fatty tissue can be used clinically with no significant difference compared to fresh fat. However, the results at eight weeks indicated that the addition of ASCs did not increase the survival rate of the fat transplants (Fig. 3).

The injections in which ASCs were added to the fresh fatty tissue and to the fat that had been frozen for one month showed higher fat survival rates at four weeks after transplantation (Tables 5, 6). This indicates that fatty tissue can be frozen and stored for up to one month if ASCs are added, with a survival

Table 3. The amount of fat tissue harvested from the mice in the control group after eight weeks

\begin{tabular}{|lccc|}
\hline Survived volume & Fresh fat & $\begin{array}{c}\text { Fat frozen for } \\
\text { 1 month }\end{array}$ & $\begin{array}{c}\text { Fat frozen for } \\
\text { 2 months }\end{array}$ \\
\hline $\begin{array}{l}\text { Average } \pm \text { standard } \\
\text { deviation }(\mathrm{mL})\end{array}$ & $0.341 \pm 0.03$ & $0.327 \pm 0.04$ & $0.209 \pm 0.02$ \\
Decrease in volume (\%) $)^{\text {a) }}$ & 31.76 & 34.52 & 58.02 \\
\hline $\begin{array}{l}\text { a) The decrease in volume was defined as [(initial volume - remnant volume)/ini- } \\
\text { tial volume] } \times 100 .\end{array}$
\end{tabular}

Table 4. The amount of fat tissue harvested from the mice in the adipose tissue-derived stem cell treatment group after eight weeks

\begin{tabular}{|lccc|}
\hline Survived volume & $\begin{array}{c}\text { Fresh } \\
\text { fat+ASCs }\end{array}$ & $\begin{array}{c}\text { Fat frozen for } \\
1 \text { month } \\
\text { +ASCs }\end{array}$ & $\begin{array}{c}\text { Fat frozen for } \\
2 \text { months } \\
\text { +ASCs }\end{array}$ \\
\hline $\begin{array}{l}\text { Average } \pm \text { standard } \\
\text { deviation (mL) } \\
\text { Decrease in volume (\%) })^{2)}\end{array}$ & $0.34 \pm 0.11$ & $0.24 \pm 0.13$ & $0.17 \pm 0.08$ \\
\hline $\begin{array}{l}\text { ASC, adipose-tissue derived stem cell. } \\
\text { a)The decrease in volume was defined as [(initial volume - remnant volume)/ini- } \\
\text { tial volume] } \times 100 .\end{array}$ & \\
\hline
\end{tabular}

Table 5. Statistical analysis of the amount of fat tissue after four weeks in transplantations that used fresh fat

\begin{tabular}{|lccc|}
\hline Group & $\begin{array}{c}\text { Mean } \\
\text { volume }\end{array}$ & $\begin{array}{c}\text { Standard } \\
\text { deviation }\end{array}$ & P-value \\
\hline Fresh fat & 0.394 & 0.05685 & 0.001 \\
Fresh fat+ASCs & 0.470 & 0.08200 & \\
\hline
\end{tabular}

ASC, adipose tissue-derived stem cell. rate similar to that of fresh fat at four weeks after transplantation.

\section{Fluorescence-activated cell sorter analysis results}

CD34 and CD45 are hematopoietic stem cell markers that were expressed in relatively small amounts in the human ASCs used for this experiment. CD73 and CD105, which are stem cell markers, were observed in $89.22 \%$ and $99.66 \%$ of the ASCs, respectively.

\section{Histological analysis of the transplanted fat}

Histological analysis using a hematoxylin and eosin stain was performed four weeks after fat transplantation. In the control group, vacuoles had formed due to the atrophy and degeneration of fat cells in the fat that had been frozen for one and two months. In contrast, in the experimental group, the shape of the fat cells was maintained even after being frozen for one or two months (Fig. 4).

More tissue transformation was observed at eight weeks than at four weeks. In particular, in the fat that had been frozen for two months, most of the adipose cells had become large or were lost. In the experimental group, the fat cells retained their original shapes to a greater extent (Fig. 5).

Fig. 3. The volume of surviving fat eight weeks after transplantation

ASC, adipose tissue-derived stem cell.

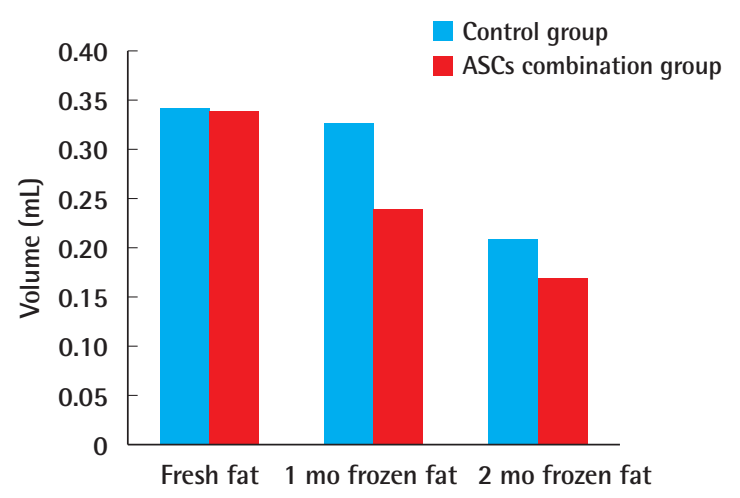

Table 6. Statistical analysis of the amount of fat tissue after four weeks in transplantations that used fat that had been frozen for one month

\begin{tabular}{|lccc|}
\hline Group & $\begin{array}{c}\text { Mean } \\
\text { volume }\end{array}$ & $\begin{array}{c}\text { Standard } \\
\text { deviation }\end{array}$ & P-value \\
\hline Fat frozen for one month & 0.387 & 0.02962 & 0.002 \\
Fat frozen for one month+ASCs & 0.440 & 0.06918 & \\
\hline ASC, adipose tissue-derived stem cell. & & & \\
\hline
\end{tabular}


Fig. 4. Histological findings four weeks after fat transplantation $\left(H \& E_{1} \times 40\right)$

(A) Fresh fat, (B) fat that had been frozen for one month, (C) fat that had been frozen for two months, (D) fresh fat+adipose tissue-derived stem cells (ASCS), (E) fat that had been frozen for one month+ASCS, (F) fat that had been frozen for two months+ASCs.
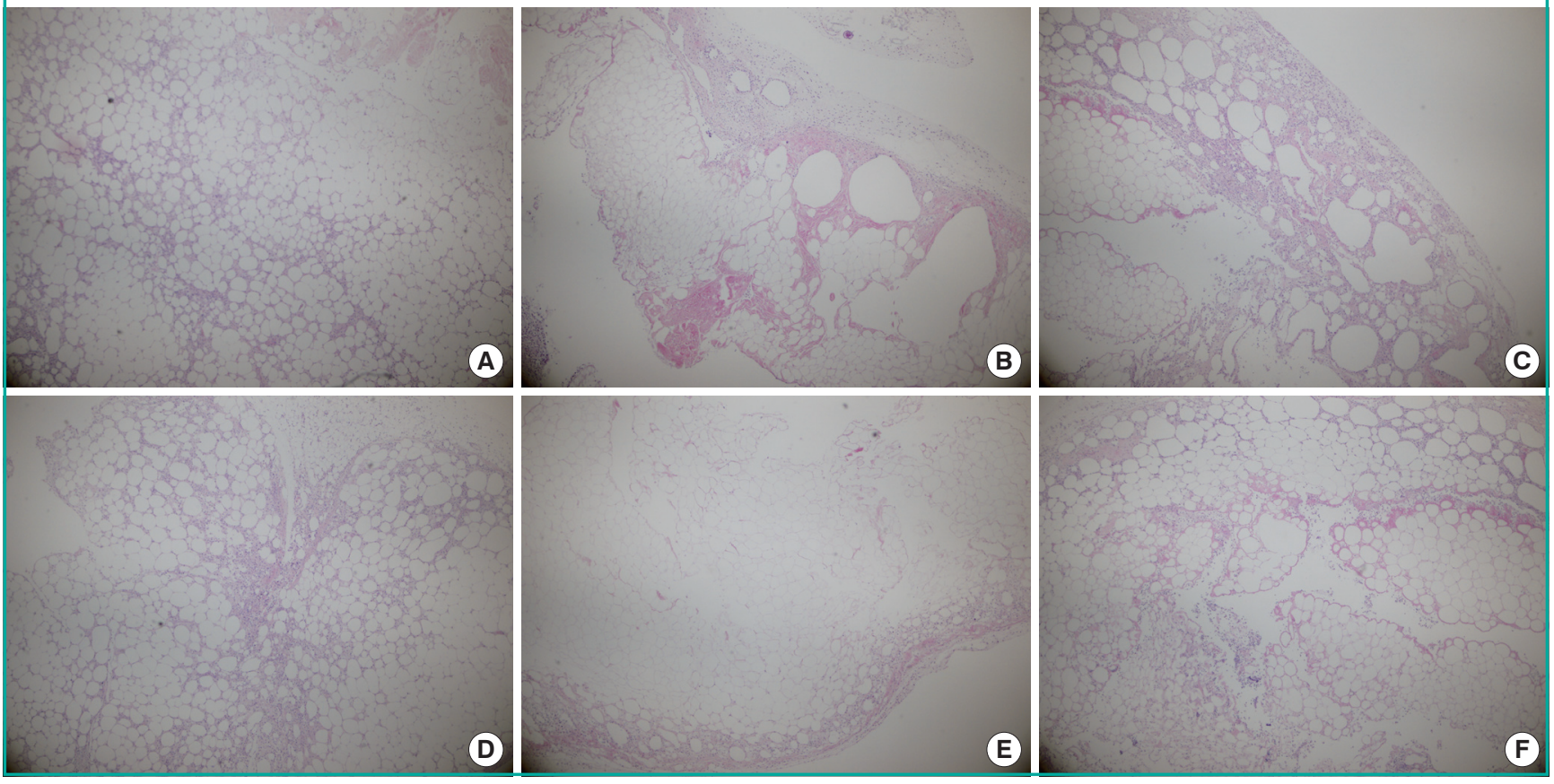

Fig. 5. Histological findings eight weeks after fat transplantation $\left(H \& E_{1} \times 40\right)$

(A) Fresh fat, (B) fat that had been frozen for one month, (C) fat that had been frozen for two months, (D) fresh fat+adipose tissue-derived stem cells (ASCS), (E) fat that had been frozen for one month+ASCs, (F) fat that had been frozen for two months+ASCs.
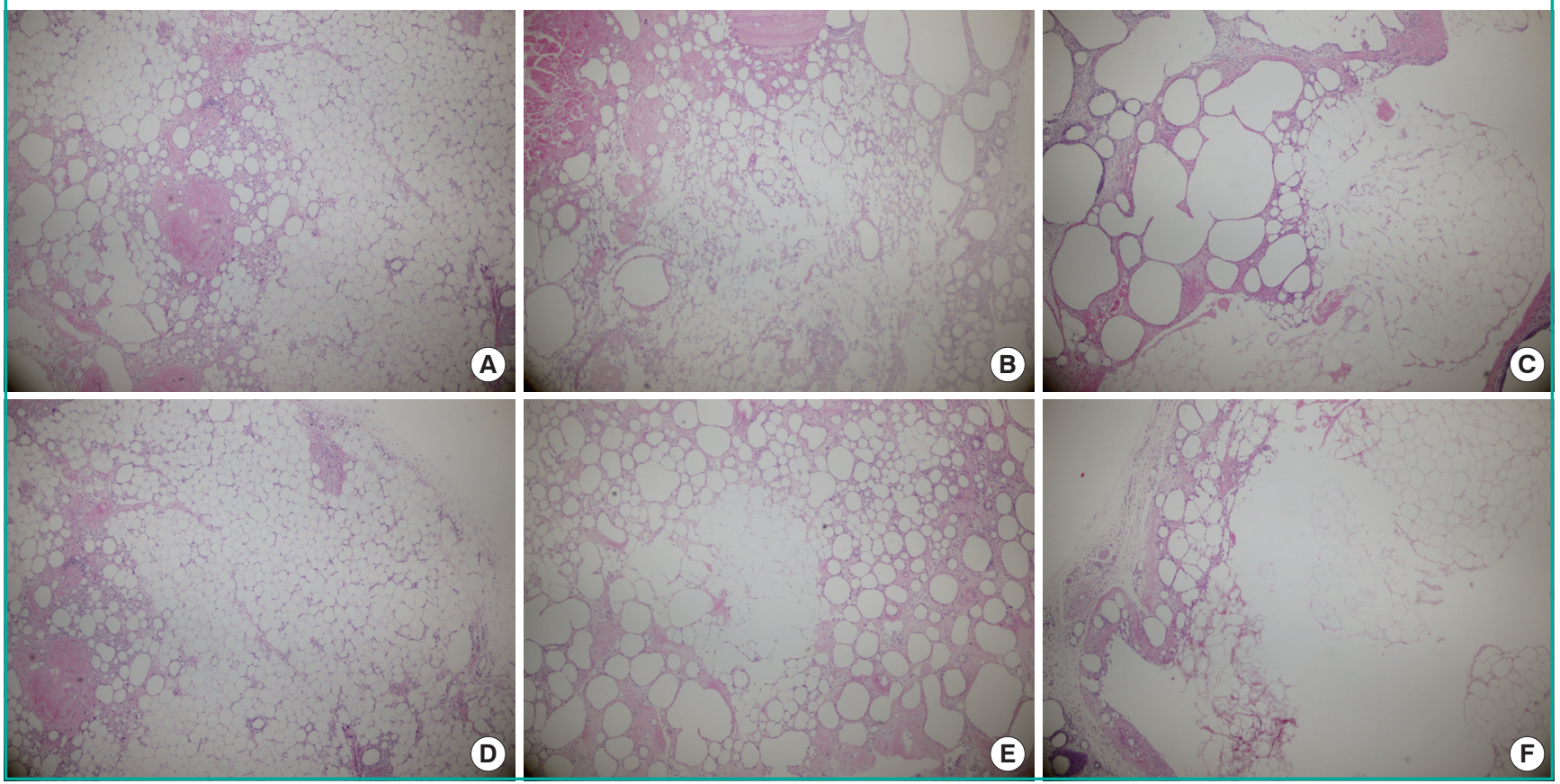

\section{DISCUSSION}

Autologous soft tissue replacement and body contour corrections have been performed using a range of methods. Skin graft- ing or free flap surgery has the drawback of donor loss, despite the efficacy of these procedures regarding the recipient sites. In contrast, fat transplantation can result in a sufficient amount of fat for soft tissue replacement, with little donor loss and fewer 
complications. However, some issues have yet to be resolved regarding fat transplantation. The reported survival rate of transplanted fat varies considerably, but normally, approximately $30 \%$ to $60 \%$ of the transplanted fat is absorbed over a period of eight to 12 months. In addition, frozen fat shows a lower survival rate after transplantation. Survival rates ranging from $5 \%$ to $15 \%$ have been reported $[11,12]$. Therefore, overcorrection and retransplantation have been implemented in order to address the high absorption rates of adipose tissue. When adipose tissue is reused after storage, the survival rate of the adipocytes is important, since adipocytes have a major impact on the engraftment of adipose tissue after reinjection [13]. Recently, a range of artificial fillers, such as hyaluronic acid, have been developed, but they are difficult to inject in large quantities and are problematic as replacements for fat transplantation. Therefore, many studies have evaluated methods of enhancing the absorption rate in fat transplantation, but it is still difficult to avoid the need for additional fat transplantation.

If additional fat transplantation is to be performed, it is of crucial importance to store the fat properly before transplantation. Shoshani et al. [14] stored human adipose tissue in a domestic refrigerator at $-18^{\circ} \mathrm{C}$, thawed it, and injected it into experimental mice. In the control group, adipose tissue freshly obtained by liposuction was injected. The survival rate analysis of the two groups showed no significant differences in weight, volume, and histological properties, meaning that the frozen fat showed a survival rate almost identical to that of the newly obtained fat. Atik et al. [15] reported that even when adipose tissue was stored at $-35^{\circ} \mathrm{C}$ in a liquid nitrogen freezer for six months, it still was similar to fresh fat with regard to survival capability and tissue structure. The freezing of adipose tissue allows multiple procedures to be performed with a single harvest of fat, despite the existence of different opinions regarding freezing methods and time periods. In addition, freezing is a technically simple procedure, and frozen fat can be stored for relatively long periods. Moreover, frozen fat is similar to fresh fat in terms of survival capacity and histological properties, making it possible to perform additional fat transplantation procedures to compensate for the low survival rate of fat transplantation.

ASCs are capable of developing into fat, bones, cartilage, muscles and nerves $[7,8]$. Therefore, adding ASCs during the fat transplantation procedure may help to improve the survival rate of transplanted fat, as the ASCs develop into fat cells. ASCs have clear similarities in shape, growth, and transcription to marrow mesenchymal stem cells, and show similar development patterns both in vitro and in vivo $[16,17]$. Therefore, ASCs can induce the endogenous recovery of bone marrow elements and can be used to reduce reperfusion injuries or cell damage upon replantation or flap reconstruction, because they secrete angiogenic factors that support the growth of existing tissue $[9,18]$. Miranville et al. [19] reported that the treatment of an ischemic muscle in a mouse with ASCs increased the survival rate of the muscle cells in the ischemic tissue. In addition, ASCs can increase the capillary density and blood flow by grafting with the host tissue. This occurs because the ASCs are grafted to the host tissue and differentiate, which results in the recovery of the functions of damaged cells or in the secretion of factors that support the host tissue.

The various functions of ASCs result in meaningful synergy in fat transplantation. Although frozen fat tissue has similar properties to freshly taken fat, freezing and thawing cannot completely avoid cell transformations. Moreover, after transplantation, fatty tissue that has been frozen will show increases in fat cell transformation and a higher fat absorption rate than fresh fatty tissue. Furthermore, excessively dense fat transplantation can result in partial necrosis due to an insufficient blood supply. ASCs can help increase the survival rate of transplanted fat cells by recovering the functionality of damaged cells and increasing the capillary density and blood flow in fat transplants.

Ko et al. [20] and Bae et al. [21] have studied the effect of human ASCs on cryopreserved fat. Both authors concluded that human ASCs enhanced the survival and quality of cryopreserved fat, but they only used fat that had been preserved for two months and evaluated the results eight weeks after implantation. Ko et al. used a stromal vascular fraction group as controls. In our study, the fat absorption rates associated with different freezing periods and different time intervals after transplantation were examined by comparing a group treated with ASCs with a control group at four and eight weeks after transplantation.

After transplantation of the fat tissue, the volume of the transplanted fat is determined by the regeneration and survival of the grafted tissues [22]. In the transplantation of frozen fat, regeneration plays a more important role than survival because the freezing process causes fat cell transformation. In our study, the fat tissue that survived and underwent regeneration after transplantation was included in the calculation of the survival rate. As observed in our study, no significant differences were found in the absorption rate between the freshly harvested fat and the fat that had been frozen for one month. However, the absorption rate was significantly higher in the injections using fat that had been frozen for two months. This phenomenon was observed both four and eight weeks after transplantation. In the experimental group, the fat absorption rate was found to be significantly lower four weeks after transplantation in injections containing fat that had been frozen for one month. Although this 
finding was less statistically significant, the absorption rate in the injections using fat that had been frozen for two months in the experimental group was different than the corresponding rate observed in the group treated without the ASCs. A histological examination showed that the injections containing ASCs maintained the original shape of the fatty tissue, even when frozen fat was used, unlike the control group. Overall, adding ASCs was found to increase the survival rate of both freshly obtained adipose tissue and adipose tissue that had been frozen for one month.

Finally, it is important to obtain a sufficient amount of ASCs when using them in autologous tissue transfer. Fortunately, large amounts of ASCs can be obtained relatively easily and inexpensively. In addition, cryopreserved ASCs can help enhance the success rate of treatment because they can be stored in large amounts and applied rapidly when necessary. According to Martinello et al. [23], the proliferative potential of ASCs decreases slightly after freezing, but their stem-cell nature and differentiation potential do not change. Their findings theoretically support the possibility that fat tissues and ASCs can be frozen, stored, and injected repeatedly. Although frozen ASCs were not used in this study, freezing both adipose tissue and ASCs prior to clinical use has the potential to reduce the expense and the number of invasive procedures. Additional research is needed to clarify these possibilities.

The use of adipose tissue-derived stem cells in fat transplantation was found to reduce the fibrosis of transplanted fatty cells and cell damage. However, using ASCs had less of an effect on the transplantation of adipose tissue that had been stored for two months. Therefore, it is desirable to frozen fat that is stored for less than 1 month is desirable.

\section{REFERENCES}

1. Rohrich RJ, Sorokin ES, Brown SA. In search of improved fat transfer viability: a quantitative analysis of the role of centrifugation and harvest site. Plast Reconstr Surg 2004;113: 391-5.

2. Boschert MT, Beckert BW, Puckett CL, et al. Analysis of lipocyte viability after liposuction. Plast Reconstr Surg 2002; 109:761-5.

3. Coleman SR. Facial recontouring with lipostructure. Clin Plast Surg 1997;24:347-67.

4. Pu LL, Cui X, Fink BF, et al. The viability of fatty tissues within adipose aspirates after conventional liposuction: a comprehensive study. Ann Plast Surg 2005;54:288-92.

5. Shiffman MA, Mirrafati S. Fat transfer techniques: the effect of harvest and transfer methods on adipocyte viability and review of the literature. Dermatol Surg 2001;27:819-26.

6. Sen A, Lea-Currie YR, Sujkowska D, et al. Adipogenic potential of human adipose derived stromal cells from multiple donors is heterogeneous. J Cell Biochem 2001;81:312-9.

7. Zuk PA, Zhu M, Mizuno H, et al. Multilineage cells from human adipose tissue: implications for cell-based therapies. Tissue Eng 2001;7:211-28.

8. Zuk PA, Zhu M, Ashjian P, et al. Human adipose tissue is a source of multipotent stem cells. Mol Biol Cell 2002;13: 4279-95.

9. Rehman J, Traktuev D, Li J, et al. Secretion of angiogenic and antiapoptotic factors by human adipose stromal cells. Circulation 2004;109:1292-8.

10. Planat-Benard V, Silvestre JS, Cousin B, et al. Plasticity of human adipose lineage cells toward endothelial cells: physiological and therapeutic perspectives. Circulation 2004;109: 656-63.

11. Cui XD, Gao DY, Fink BF, et al. Cryopreservation of human adipose tissues. Cryobiology 2007;55:269-78.

12. Hwang SM, Lee JS, Kim HD, et al. Comparison of the viability of cryopreserved fat tissue in accordance with the thawing temperature. Arch Plast Surg 2015;42:143-9.

13. Ramon Y, Shoshani O, Peled IJ, et al. Enhancing the take of injected adipose tissue by a simple method for concentrating fat cells. Plast Reconstr Surg 2005;115:197-201.

14. Shoshani O, Ullmann Y, Shupak A, et al. The role of frozen storage in preserving adipose tissue obtained by suction-assisted lipectomy for repeated fat injection procedures. Dermatol Surg 2001;27:645-7.

15. Atik B, Ozturk G, Erdogan E, et al. Comparison of techniques for long-term storage of fat grafts: an experimental study. Plast Reconstr Surg 2006;118:1533-7.

16. Katz AJ, Tholpady A, Tholpady SS, et al. Cell surface and transcriptional characterization of human adipose-derived adherent stromal (hADAS) cells. Stem Cells 2005;23:41223.

17. Pittenger MF, Martin BJ. Mesenchymal stem cells and their potential as cardiac therapeutics. Circ Res 2004;95:9-20.

18. Cousin B, Andre M, Arnaud E, et al. Reconstitution of lethally irradiated mice by cells isolated from adipose tissue. Biochem Biophys Res Commun 2003;301:1016-22.

19. Miranville A, Heeschen C, Sengenes C, et al. Improvement of postnatal neovascularization by human adipose tissue-derived stem cells. Circulation 2004;110:349-55.

20. Ko MS, Jung JY, Shin IS, et al. Effects of expanded human adipose tissue-derived mesenchymal stem cells on the viability of cryopreserved fat grafts in the nude mouse. Int J Med Sci 2011;8:231-8. 
21. Bae YC, Song JS, Bae SH, et al. Effects of human adiposederived stem cells and stromal vascular fraction on cryopreserved fat transfer. Dermatol Surg 2015;41:605-14.

22. Kim M, Kim I, Kim SH, et al. Cryopreserved human adipogenic-differentiated pre-adipocytes: a potential new source for adipose tissue regeneration. Cytotherapy 2007;9:468-
76.

23. Martinello T, Bronzini I, Maccatrozzo L, et al. Canine adipose-derived-mesenchymal stem cells do not lose stem features after a long-term cryopreservation. Res Vet Sci 2011; 91:18-24. 